How to Cite

Khanum, K., \& Siddiqui, F. H. (2018). Difficulties of students in English as a medium, a sociolinguistic study of the government colleges in the rural areas of Quetta and Zhob divisions of Baluchistan. International Journal of Social Sciences, 1(1), 18-30.

https://doi.org/10.31295/ijss.v1n1.14

\title{
Difficulties of Students in English as a Medium, a Sociolinguistic Study of the Government Colleges in the Rural Areas of Quetta and Zhob Divisions of Baluchistan
}

\author{
Khatima Khanum \\ Hamdard University Karachi, Karachi, Pakistan \\ Corresponding author email: khatkhunam@yahoo.com \\ Fakhrul Hoda Siddiqui \\ Hamdard University of Karachi, Karaci, Pakistan
}

\begin{abstract}
The general purpose of the study was to analyze the factors, due to which students of Quetta and Zhob Divisions of Baluchistan province are facing difficulties regarding English as a medium. The study investigated the factors which were affecting the student's efficiency regarding English learning. What was the role of the teacher in improving English among rural area's students? How was a student facilitated, to make English easier for him? How trained and qualified teachers use different teaching methods to make English an easier subject for students? All students of the rural areas are not aware of the importance of English in today's world. All students do not have equal opportunities to get an education in good English medium schools. The study was expected to provide strategies for the improvement of teaching-learning environment for the subject of English. The study was investigated to benefit the teachers in understanding the important methods of teaching English and importance of the role of the teachers. Role of a teacher regarding English teaching and role of students regarding English learning was highlighted. Most of the students were unaware of the importance of English nowadays. Most of the students were unfamiliar to English linguistics. Many teachers were unaware of the importance of effective English teaching methods. Untrained teachers not only spoil the institutions but its educational setup too. Most of the rural area's students have no base in English.

Keywords---baluchistan, government, sociolinguistic.
\end{abstract}

\section{Introduction}

English was introduced in the areas now comprising Pakistan by the domains of power government bureaucracy, judiciary, military, education, commerce, media etc. at the elitist level; it became a preserve of the elite and a means of empowerment. It also became a status symbol marker-and a social asset, thus function as a class differentiator. The role of English has become more pronounced in the recent years because the elites of Pakistan especially the armed force and the bureaucracy have appropriated English for themselves contrary to the state's declared policy of curtailing its role and replacing it with Urdu, the national language, as the official language (Rehman, 1999).

Educators are concerned that the English language is taught in that country under conditions which are far from being satisfactory. English plays a prominent role in Pakistan as a lingua franca - a common means of communication - besides Urdu and a host of regional languages and numerous dialects - as a global language and a medium for science and technology. However, it is a fact that despite studying English in schools and colleges for about 6-8 years, students, especially coming from rural backgrounds, are not able to communicate in English with relative ease and success. Even in some areas where students use a regional language as a first language (L1) besides Urdu - and in such areas English becomes a third language (L3) - they lack all the four major linguistic skills reading, writing, listening, and speaking. Since acquiring a second language is a skill, it should be approached in that

ISSN 2632-9409

Received Jan 10, 2018 / Accepted Jun 20, 2018 / Published Jul 05, 2018 
light. It is clear that the methods of teaching the English language in Pakistan have not yielded the desired objective, i.e. communicative competence. In this paper, I argue that educators, second language acquisition researchers, and English language teachers in Pakistan must approach teaching English as a Second Language from the perspective of applied linguistics and take the necessary measures to ameliorate the conditions under which English is taught in both rural and urban areas (Rehman, 1999).

\section{Focus of the study}

In this paper, the focus is on the issue of sociological and linguistic problems of the English language in rural areas of Zhob and Quetta. The purpose is to give the reader a critical analysis of the English language as a medium of instruction and as the main factor in determining the social and linguistic strata of the young generation in these areas. It also purports to highlight the problems with the policies of the government and the responses of the people regarding this medium. It details how this medium has divided and stratified society.

\section{Review of the related literature}

The foundation of this research study is based on the opinions/suggestions of well-known research scholars in the field of English. Sabiha (2002) is of the view that Pakistani students, their teachers, parents, and the administrators of universities, positive attitudes towards English.it goes on to recommend that English should continue to be used as an alternate medium of instruction for government schools till class 12 (Sabiha Mansoor, 2002). Rehman (1999) gives his view that English would also be the medium of instruction in higher education. these recommendations, if implemented, will not change the power question because only a few urban government schools would be able to use English as a medium of instruction as, indeed, the model schools of Islamabad are already doing. All other schools would be forced to keep using Urdu as they would neither have the teachers nor the texts to use English effectively (Rehman, 1999). Mansoor (1993) also found that Students have a linguistic hierarchy in mind with English at the top followed by Urdu and with the mother tongue, in this case, Punjabi, coming to the bottom. English is associated with informality and intimacy (Mansoor 1993). In recent years; English has become the language of globalization and, therefore, dominates the world. Thus Pakistanis seeking access to the international market also need English. Indeed while state jobs in Pakistan have become accessible for people who have average proficiency in English, the wellpaying NGOs, the private educational institutions, the corporate sector and the most fashionable society all need very high proficiency in English. Thus, fifty-seven years after independence from British rule, Pakistanis find themselves more in need of English than ever before. It was, and remains, the modernizing Pakistanis' major hope for empowerment as long as the present policies, which favor English remain intact (Hamza Alvai, 1987). English is taught as a subject in the vernacular-medium schools either from class-1 or class- 6 throughout Pakistan.it is also compulsory in the higher secondary level (classes 11 and 12) and the two year bachelor's level $(13 \& 14$ years of education) However, the level of competence attained is low and students are unable to understand and write, let alone speak, English. English taught through the grammar-translation method. Students memorize a large number of rules without acquiring any real understanding of the language. The students cram lessons, such as essays, from the guidebooks and get passing grades without acquiring any real competence in English. Passing percentages in Urdu, and overall passing percentages are better than in English (Rehman, 1991).

\section{Objectives}

This work is intended to explore the socio-linguistic impacts of English as a medium of instruction at educational institutes in Quetta and Zhob division of Baluchistan. Among many purposes to be explored some of the main objectives are given as under:

1) To analyze those factors, due to which students of Quetta and Zhob divisions of Baluchistan province are facing difficulties regarding English as a medium of instruction.

2) To evaluate and improve the quality of English teaching.

3) To find out those factors which affect student's efficiency regarding English. Learning

4) To find out facilities to make English easier for rural areas students

5) To know how to develop a better environment in a rural area for learning and teaching English.

6) To examine and find out the different skills among teacher that make English subject easier and interesting for rural areas students. 


\section{Hypotheses}

As most of the quantitative research needs hypotheses to revolve around them. Following hypotheses were developed to be tested.

Hypothesis No1: Due to the lack of qualified teachers, students are weak in English.

Hypothesis No2: Due to the lack of pre-planned syllabi students face difficulties in learning English.

Hypothesis No3: Low-income people do not teach their children in English medium schools.

\section{Research Method}

The study was quantitative in nature. The present study is descriptive because of the nature of the problem.52 colleges of Quetta and Zhob divisions of Baluchistan province (22 colleges of girls and 30 colleges of boys) has been chosen for the study. The population of the universe was 32868 students of rural areas of Quetta and zhob divisions. In this present study, the researcher has taken the sample of 384 respondents. The simple random sampling method was used for the selection of the sample. The questionnaire was used as a tool to collect the data. Questionnaires were prepared after pilot testing and distributed by a personal visit to the institutions of Quetta and Zhob divisions of Balochistan province. Chi-square test has been used to analyze the data.

\section{Results and Analysis}

\section{Data Analysis}

In this paper, the data is analyzed in simple tabulation representing. English is the medium of instruction and other information obtained through the questionnaire. The factor on which information is tabulated is including Respondents qualification level, family members, monthly income and father's occupation, the importance of English and role of English etc.

Table1

Monthly income of the respondent's family

\begin{tabular}{lll}
\hline Monthly income & Frequency & Percentage \\
\hline No income & 24 & 6.25 \\
Up to 10,000 & 90 & 23.37 \\
$10,001-20,000$ & 121 & 31.42 \\
$20,001-30,000$ & 68 & 17.66 \\
$30,001-40,000$ & 37 & 9.61 \\
$40,001-50,000$ & 25 & 6.49 \\
Above 5,0000 & 19 & 4.93 \\
TOTAL & 384 & $100.00 \%$
\end{tabular}




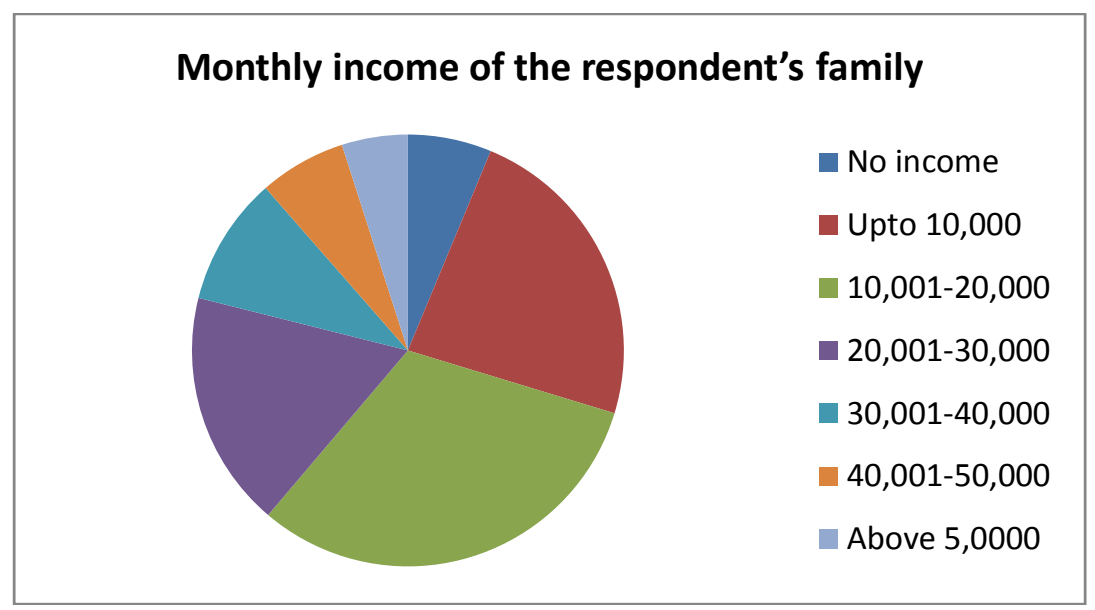

Figure 1. Monthly Income of The Respondent's Family

The above table indicates that the highest numbers of respondents (parents) are those whose monthly income is $10,001-20,000$ thousand, which form $31.42 \%$ out of $100 \%$ of the total people.

The second highest numbers of respondents are those whose monthly income is up to-10,000 thousand with the percentage of $23.37 \%$.

The third highest numbers of respondents are those whose monthly is 20,001-30,000 thousand with the percentage of $17.66 \%$.

The fourth highest number of respondents have their monthly income upto30,001-40000 thousands with the percentage of $17.66 \%$.

$6.49 \%$ are those who have no income.

The last highest numbers of respondents are having above 5oooothousands with the percentage of $4.93 \%$.

We can say that majority of the respondents have their monthly income up to Rs $20000 /=$ who is $61.20 \%$. Whereas $38.80 \%$ have their monthly income more than Rs 20000.

Table 2

An untrained teacher affects student's efficiency regarding the English language

\begin{tabular}{lll}
\hline Yes/No & Frequency & Percentage \\
\hline yes & 345 & 89.61 \\
no & 39 & 10.12 \\
Total & 384 & $100 \%$ \\
\hline
\end{tabular}

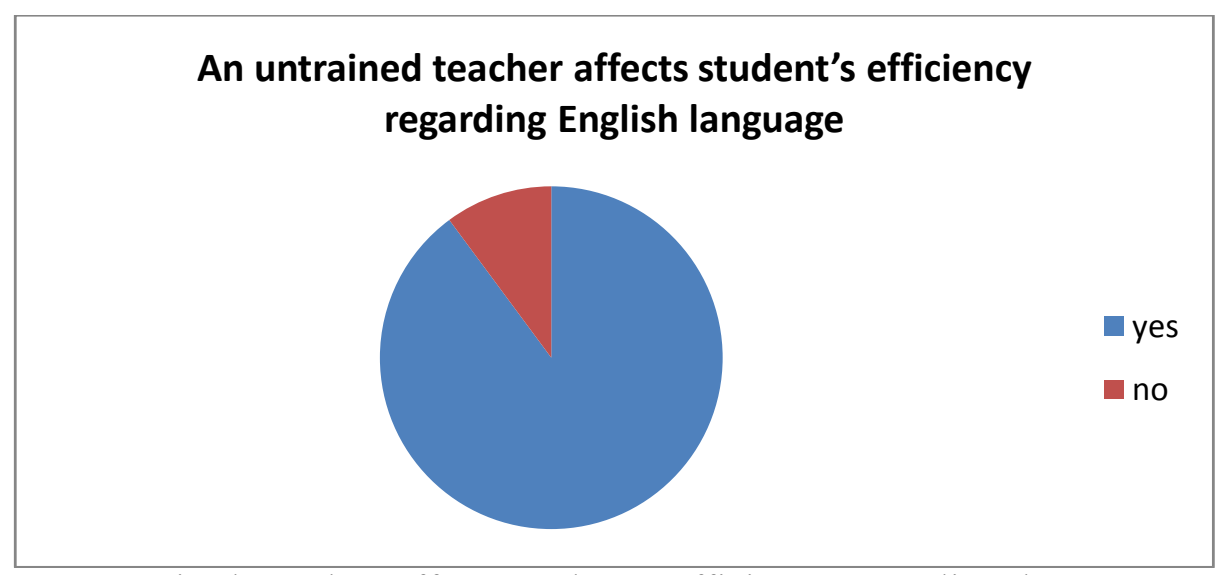

Figure 2. An Untrained Teacher Affects Student's Efficiency Regarding the English Language 
This table indicates that the highest numbers of students who agree that an untrained teacher affects student's efficiency regarding the English language are $89.61 \%$ out of $100 \%$ while less number of the students does not agree with the percentage of 10.12 out of $100 \%$

Table 4

Do you agree that students of Government colleges of the rural areas of Quetta and Zhob divisions are weak in English?

\begin{tabular}{lll}
\hline Yes/No & Frequency & Percentage \\
\hline yes & 361 & 93.76 \\
no & 23 & 5.97 \\
Total & 384 & $100 \%$ \\
\hline
\end{tabular}

\section{students of Government colleges of the rural areas of Quetta and Zhob divisions are weak in English}

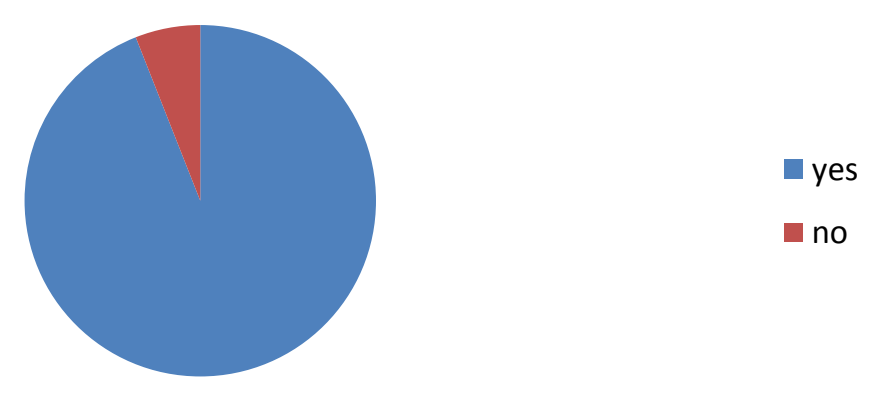

Figure 4. Do you agree that students of government colleges of the rural areas of Quetta and zhob divisions are weak in English?

This table indicates that the highest number of students who agree that, the students of Government colleges of the rural areas of Quetta and Zhob divisions are weak in English, is 93.76 out of 100\%, while less number of students disagree, and makes a percentage of 5.97 out of $100 \%$.

Table 5

Do you agree that there are no preplanned syllabi in the Government colleges of the rural areas of Quetta and Zhob divisions?

\begin{tabular}{ccc}
\hline Yes/No & Frequency & Percentage \\
\hline yes & 331 & 85.97 \\
no & 53 & 13.76 \\
Total & 384 & $100 \%$ \\
\hline
\end{tabular}

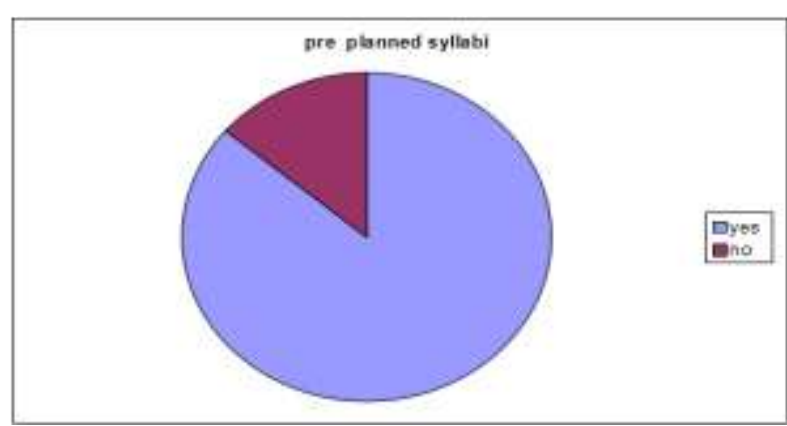

Figure 5. Do you agree that there are no preplanned syllabi in the government colleges of the rural areas of Quetta and zhob divisions? 
This table indicates that the highest number of students who agree that there are no preplanned syllabi in the Government colleges of the rural areas of Quetta and Zhob divisions are 85.97out of 100\%, while those students who disagree make a percentage of 13.76 out of $100 \%$.

Table 6

Do you agree that our teachers at colleges are well qualified for English teaching?

\begin{tabular}{lll}
\hline Yes/No & Frequency & Percentage \\
\hline yes & 173 & 45.05 \\
no & 211 & 54.94 \\
Total & 384 & $100 \%$ \\
\hline
\end{tabular}

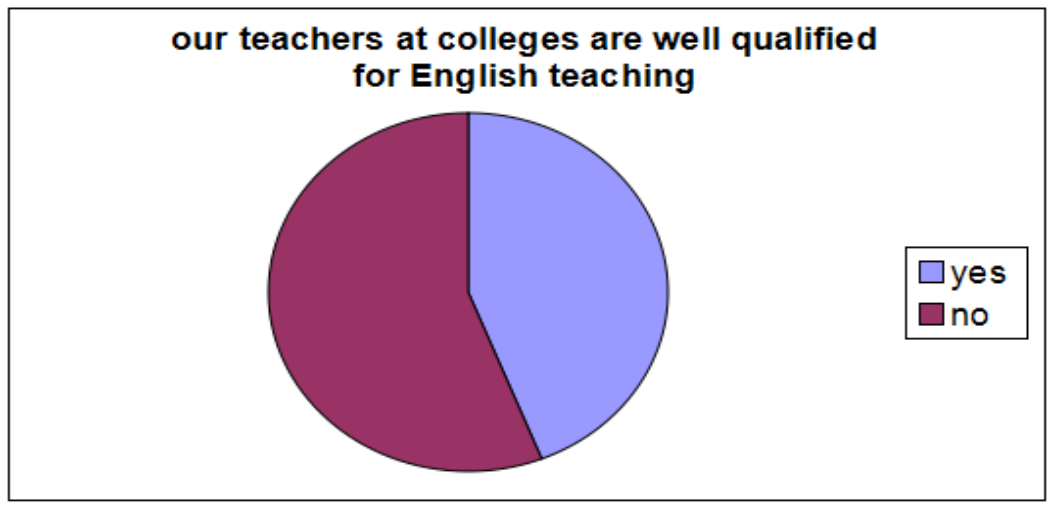

Figure 6. Do you agree that our teachers at colleges are well qualified for English teaching?

This table indicates that a minimum number of students agree that, our teachers at colleges are well qualified for English teaching, are 43.89 out of $100 \%$, while the majority of the students disagree, and makes a percentage of 55.84 out of $100 \%$.

Table 7

Most of the teachers in schools of rural areas are mainly unaware of the importance of effective English teaching process

\begin{tabular}{lll}
\hline Yes/No & Frequency & Percentage \\
\hline yes & 332 & 86.23 \\
no & 52 & 13.50 \\
Total & 384 & $100 \%$ \\
\hline
\end{tabular}

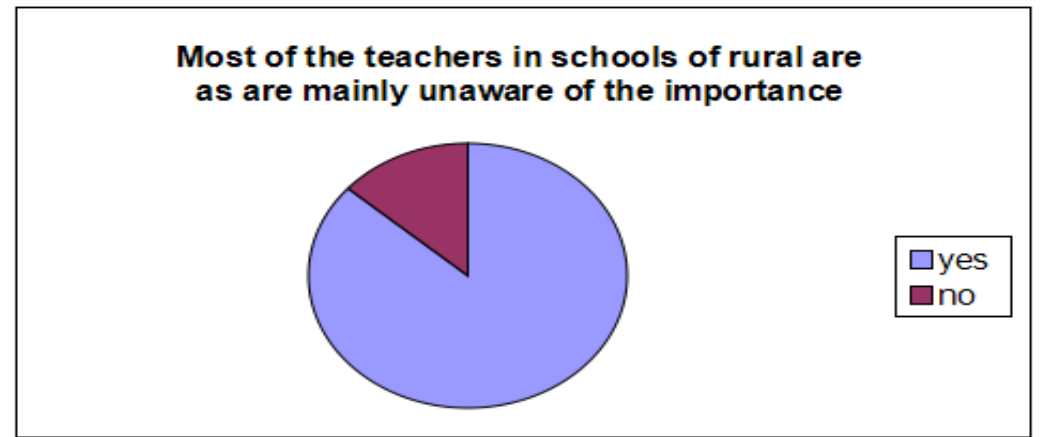

Figure 7. Most of The Teachers In Schools of Rural Areas Are Mainly Unaware of The Importance of Effective English Teaching Process. 
This table indicates that the highest number of students who agree that, most of the teachers in schools of rural areas are mainly unaware of the importance of effective English teaching process, are 86.23out of 100\%, while less number of students disagree, and makes a percentage of 13.50 out of $100 \%$.

Table 8

Do you agree that the students at government colleges of Quetta and Zhob divisions facing difficulties in English learning

\begin{tabular}{lll}
\hline Yes/no & Frequency & Percentage \\
\hline Yes & 358 & 92.98 \\
No & 26 & 6.75 \\
Total & 384 & $100 \%$ \\
\hline
\end{tabular}

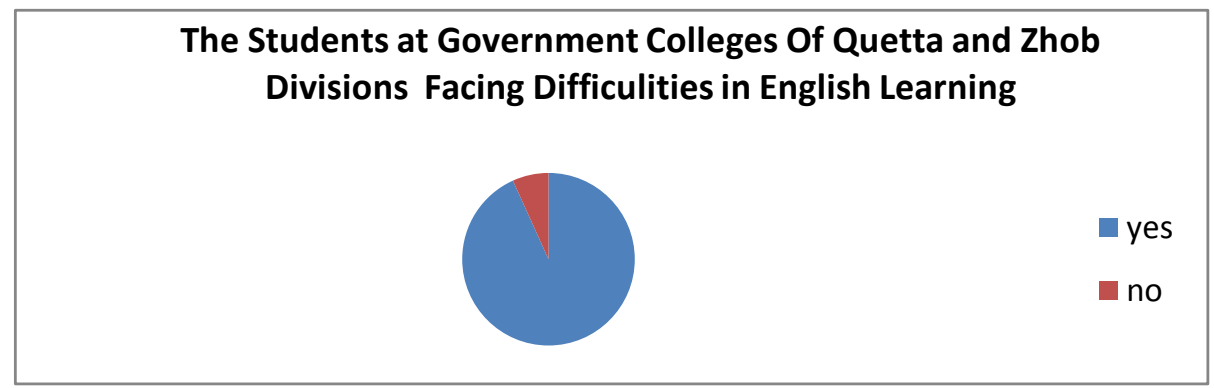

Figure 8. Do you agree that the students at government colleges of Quetta and zhob divisions facing difficulties in English learning?

This table indicates that the highest number of students who agree that, the students at government colleges of Quetta and Zhob divisions facing difficulties in English learning, are 92.98 out of $100 \%$, while those students who disagree, make a percentage of 6.75 out of $100 \%$.

Table 9

Do you agree that most of the people of rural areas are poor that's why they cannot give education to their children in private English medium schools

\begin{tabular}{ccc}
\hline Yes/No & Frequency & Percentage \\
\hline yes & 286 & 74.28 \\
no & 98 & 25.45 \\
Total & 384 & $100 \%$ \\
\hline
\end{tabular}




\section{most of the people of rural areas are poor that's why they can not give education to their children in private English medium schools}

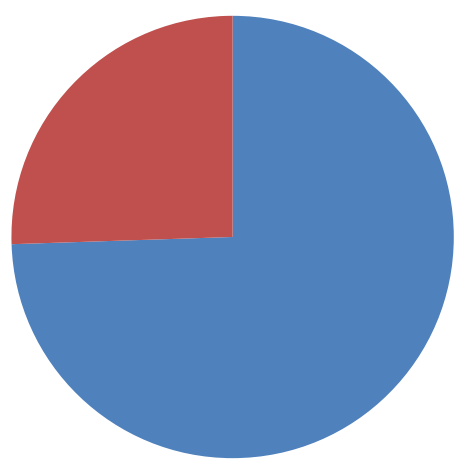

Figure 8. Do you agree that most of the people of rural areas are poor that's why they can not give education to their children in private English medium schools

This table indicates that the highest number of students who agree that most of the people of rural areas are poor that's why they cannot give education to their children in private English medium schools, are 74.28 out of 100\%, while those students who disagree, make a percentage of 25.45 out of $100 \%$.

\section{Hypothesis No. 1}

Due to the lack of Qualified Teachers, students are weak in English:

Null Hypothesis

There is no relationship between Qualified Teachers and Students' weakness in English.

Table 4-6

\begin{tabular}{cccc}
\hline Qualified Teachers & \multicolumn{2}{c}{ Students Weak In English Learning } & Total \\
\cline { 2 - 3 } & \multicolumn{2}{c}{ Yes } & \\
\hline Yes & \multicolumn{2}{c}{$165_{163} 8_{10}$} & 173 \\
No & \multicolumn{2}{c}{$196_{198} 15_{13}$} & 211 \\
Total & & 23 & 384 \\
\hline
\end{tabular}

As $(f o-f e)^{2}$

$0.0245+0.4000+0.0202+0.3076$

$$
\begin{gathered}
\frac{\left(f_{o}-f_{e}\right)^{2}}{f_{e}}+\frac{\left(f_{o}-f_{e}\right)^{2}}{f_{e}}+\frac{\left(f_{o}-f_{e}\right)^{2}}{f_{e}}+\frac{\left(f_{o}-f_{e}\right)^{2}}{f_{e}} \\
\frac{(165-163)^{2}}{163}+\frac{(8-10)^{2}}{10}+\frac{(196-198)^{2}}{198}+\frac{(15-13)^{2}}{13} \\
\frac{(2)^{2}}{163}+\frac{(-2)^{2}}{10}+\frac{(-2)^{2}}{198}+\frac{(2)^{2}}{13} \\
\frac{4}{163}+\frac{4}{10}+\frac{4}{198}+\frac{4}{13}
\end{gathered}
$$

The calculated value is $=0.7523$

$x^{2} \propto$ at $(c-1)(r-1)$ degrethe e of freedom with 0.05 significance value.

$x^{2} \propto$ at $(2-1)(2-1)$ degthe ree of freedom with 0.05 significance value. 
$x^{2} \propto$ The at $1 \times 1$ degree of freedom with 0.05 significance value.

$x^{2} \propto$ at 1 degree of freedom with 0.05 significance value.

$x^{2} \propto$ at 3.481 (tabulated value)

the calculated value 0.7523 is lesser than tabulated value 3.481 . Hence, the hypothesis is rejected and alternate hypothesis is upheld i.e. there is a significant relationship between the weakness of students in the English learning and the teachers ....

The above table indicates the null hypothesis was proved that shows that no relationship exists between students weakness in English and qualified teachers.

Hypothesis No. 2

Due to the lack of Preplanned Syllabi students face difficulties in learning English

Null Hypothesis

There is no relationship between Preplanned Syllabi and students' difficulties in English learning

Table 5-8

\begin{tabular}{cccc}
\hline $\begin{array}{c}\text { Pre-planned } \\
\text { Syllabi }\end{array}$ & $\begin{array}{c}\text { Students 'difficulties in English learning } \\
\text { Yes }\end{array}$ & No \\
\hline Yes & \multicolumn{2}{c}{$313_{309} 18_{22}$} & 331 \\
No. & & $45_{49} 8_{4}$ & 53 \\
Total & 358 & & 26 \\
\hline
\end{tabular}

As $(f o-f e)^{2}$

$f e \stackrel{(f o-f e)^{2}}{-}$

$$
\begin{gathered}
\frac{\left(f_{o}-f_{e}\right)^{2}}{f_{e}}+\frac{\left(f_{o}-f_{e}\right)^{2}}{f_{e}}+\frac{\left(f_{o}-f_{e}\right)^{2}}{f_{e}}+\frac{\left(f_{o}-f_{e}\right)^{2}}{f_{e}} \\
\frac{(313-309)^{2}}{309}+\frac{(18-22)^{2}}{22}+\frac{(45-49)^{2}}{49}+\frac{(8-4)^{2}}{4} \\
\frac{(4)^{2}}{309}+\frac{(-4)^{2}}{22}+\frac{(-4)^{2}}{49}+\frac{(4)^{2}}{4} \\
\frac{16}{309}+\frac{16}{22}+\frac{16}{49}+\frac{16}{4}
\end{gathered}
$$

$0.0517+0.7272+0.3265+4.0$

The calculated value is $=5.1054$

$x^{2} \propto$ at $(c-1)(r-1)$ degrethe e of freedom with 0.05 significance value.

$x^{2} \propto$ at $(2-1)(2-1)$ degthe ree of freedom with 0.05 significance value.

$x^{2} \propto$ at $1 \times 1$ degree of freedom with 0.05 significance value.

$x^{2} \propto$ at 1 degree of freedom with 0.05 significance value.

$x^{2} \propto$ at 3.481 (tabulated value)

Here the calculated value 5.1054 is bigger than tabulated value 3.481 . Hence, the hypothesis is accepted. There is .... The above table indicates that the null hypothesis was disproved that shows the relationship exists between preplanned syllabi and students difficulties in learning English

Hypothesis No. 3

Fewer income people do not teach their children in English medium schools

Null Hypothesis

There is no relationship between less income and don't teach their children in English medium schools 
Table 1-9

\begin{tabular}{|c|c|c|c|}
\hline \multirow[t]{2}{*}{ Less income } & \multicolumn{2}{|c|}{ Don't teach their children in English medium schools } & \multirow[t]{2}{*}{ Total } \\
\hline & Yes & No & \\
\hline Less income & $80_{85}$ & $34_{29}$ & 114 \\
\hline Better income & $206_{201}$ & 6469 & 270 \\
\hline Total & 28698 & & 384 \\
\hline
\end{tabular}

As $(f o-f e)^{2}$

fe

$$
\begin{gathered}
\frac{\left(f_{o}-f_{e}\right)^{2}}{f_{e}}+\frac{\left(f_{o}-f_{e}\right)^{2}}{f_{e}}+\frac{\left(f_{o}-f_{e}\right)^{2}}{f_{e}}+\frac{\left(f_{o}-f_{e}\right)^{2}}{f_{e}} \\
\frac{(80-85)^{2}}{85}+\frac{(34-29)^{2}}{29}+\frac{(206-201)^{2}}{201}+\frac{(64-69)^{2}}{69} \\
\frac{(-5)^{2}}{85}+\frac{(5)^{2}}{29}+\frac{(5)^{2}}{201}+\frac{(-5)^{2}}{69} \\
\frac{25}{85}+\frac{25}{29}+\frac{25}{201}+\frac{25}{69}
\end{gathered}
$$

$0.2941+0.8620+0.1243+0.3623$

$x^{2} \propto$ at $(c-1)(r-1)$ degrethe e of freedom with 0.05 significance value.

$x^{2} \propto$ at $(2-1)(2-1)$ degthe ree of freedom with 0.05 significance value.

$x^{2} \propto$ at $1 \times 1$ degree of freedom with 0.05 significance value.

$x^{2} \propto$ at 1 degree of freedom with 0.05 significance value.

$x^{2} \propto$ at 3.481 (tabulated value)

The calculated value is $=1.6427$

$x^{2} \alpha$ at 01 degrees of freedom with 0.05 significance value the tabulated value is 3.841

Here the calculated value1.6427 is lesser than tabulated value 3.841. Hence, the hypothesis is rejected.

The above table indicates the null hypothesis was proved that shows that no relationship exists between less income and parents not educating their children in English medium schools.

\section{Findings}

1. Monthly income

a. We find that majority of the respondents have their monthly income up to Rs $20000 /-$ who are $61.20 \%$.

b. Whereas $38.80 \%$ have their monthly income more than Rs 20000

2. An untrained teacher effects student's efficiency

a. We find that the highest number of students are agreed that an untrained teacher affects student's efficiency regarding the English language is $89.61 \%$ out of $100 \%$ while less number of the students does not agree with the percentage of 10.12 out of $100 \%$.

3. Students of the rural areas of Quetta and Zhob divisions are weak in English

a. The highest number of students are agreed that there should be a better environment for learning and teaching English are $91.68 \%$ out of $100 \%$, while less number of students disagree, and makes a percentage of 8.05 out of $100 \%$.

4. Pre-planned syllabi in the govt. colleges of rural areas of Quetta and Zhob divisions

a. We find that the highest number of students are agreed that, the students of Government colleges of the rural areas of Quetta and Zhob divisions are weak in English, are 93.76 out of 100\%, while less number of students disagree, and makes a percentage of 5.97 out of $100 \%$.

5. Teachers at rural areas colleges are well qualified for English teaching

a. The minimum number of students are agreed that our teachers at colleges are well qualified for English teaching, are 43.89 out of $100 \%$, while the majority of the students disagree, and makes a percentage of 55.84 out of $100 \%$. 
6. The teachers in colleges of rural areas are mainly unaware of the importance of effective English teaching process.

a. We find that most of the students are agree that, most of the teachers in schools of rural areas are mainly unaware of the importance of effective English teaching process, are 86.23out of 100\%, while less number of students disagree, and makes a percentage of 13.50 out of $100 \%$.

7. The students at government colleges of Quetta and Zhob divisions facing difficulties in English learning

a. We find that the highest number of students are-agreed with the statement that, the students at government colleges of Quetta and Zhob divisions facing difficulties in English learning, are 92.98 out of $100 \%$, while those students who disagree and makes a percentage of 6.75 out of $100 \%$.

8. The people of rural areas are poor that's why they cannot give education to their children in private English medium schools

a. We come to know that the highest number of students are agreed that most of the people of rural areas are poor that's why they cannot give education to their children in private English medium schools, are 74.28 out of $100 \%$, while those students who disagree, make a percentage of 25.45 out of $100 \%$.

\section{Conclusion}

To conclude, the learning environment in which English is taught in Pakistan is not favorable to teach and learn the English language. kills; moreover the teachers teaching the English language are strictly needed to be trained as well as Courses of English are taught without any specific objectives, to enhance the language skills or writing the efficient pedagogical tools; appropriate textbooks must be designed to teach English as a Second Language which is lacking till to date; language teaching facilities are not equipped with audiovisual aids; and the education system is lacking an observation and feedback mechanism.

It is recommended that the Department of Education in Pakistan seriously consider designing English as a Second Language courses with specific curricular objectives, paying close attention to the proficiency levels of the students; training teachers to ensure that they are well equipped for understanding the complicated process of second language acquisition and for teaching the English language to the Pakistanis; abandoning the Translation Method and incorporating Content based Instruction in language teaching; adopting appropriate textbooks that link theory to application; using audio-visual aids to enhance the vast amount of input and raise the learner's consciousness of the target language; administering tests that accurately gauge the learner's performance behavior; and envisaging a feedback mechanism that allows for professional development in a non-threatening, unobtrusive, and collegial manner.

\section{Acknowledgements}

The author would like to thank the editor for their valuable time and advice. 


\section{References}

Aldridge, J., \& Goldman, R. L. (2007). Current issues and trends in education. Allyn \& Bacon.

Bhatti, M. A., \& Afzal, M. M. (1987). Secondary Education in Pakistan: Perspective Planning (No. 2). National Education Council.

Coombs, P. H., \& Ahmed, M. (1974). Attacking Rural Poverty: How Nonformal Education Can Help. A Research Report for the World Bank Prepared by the International Council for Educational Development.

Crystal, D. (2011). A dictionary of linguistics and phonetics(Vol. 30). John Wiley \& Sons.

Curtis, B., \& Curtis, C. (2011). Social research: A practical introduction. Sage.

Devi, D. U. (2007). Environmental Education for Rural Population. Discovery Publishing House.

District Development Profile 2011.july 18 th 2012. Killa Saifullah. Prepared by planning and Development Department, Government of Balochistan, Quetta(in collaboration with) UNICEF United NationnChildren's fund provincial office in Balochistan, Quetta.pg 77.

District Development Profile 2011.july $18^{\text {th }}$ 2012. Sherani. Prepared by planning and Development Department, Government of Balochistan, Quetta(in collaboration with) UNICEF United NationnChildren's fund provincial office in Balochistan, Quetta.pg 54.

District DevelopmentProfile 2011.july $18^{\text {th }}$ 2012. Barkhan. Prepared by planning and Development Department, Government of Balochistan, Quetta(in collaboration with) UNICEF United NationnChildren's fund provincial office in Balochistan, Quetta.pg 74.

District DevelopmentProfile 2011.july $18^{\text {th }}$ 2012. Killa Abdullah. Prepared by planning and Development Department, Government of Balochistan, Quetta(in collaboration with) UNICEF United NationnChildren's fund provincial office in Balochistan, Quiet ta.pg 71.

District DevelopmentProfile 2011.july $18^{\text {th }}$ 2012. Loralai. Prepared by planning and Development Department, Government of Balochistan, Quetta(in collaboration with) UNICEF United NationnChildren 's fund provincial office in Balochistan, Quetta.pg 81.

District DevelopmentProfile 2011.july $18^{\text {th }}$ 2012. Musakhail. Prepared by planning and Development Department, Government of Balochistan, Quetta(in collaboration with) UNICEF United NationnChildren's fund provincial office in Balochistan, Quetta.pg 72.

District DevelopmentProfile 2011.july 18 ${ }^{\text {th }}$ 2012. Pishin. Prepared by planning and Development Department, Government of Balochistan, Quetta(in collaboration with) UNICEF United NationnChildren's fund provincial office in Balochistan, Quetta.pg 80.

District DevelopmentProfile 2011.july $18^{\text {th }}$ 2012. Quetta. Prepared by planning and Development Department, Government of Balochistan, Quetta(in collaboration with) UNICEF United NationnChildren's fund provincial office in Balochistan, Quetta.pg 82.

District DevelopmentProfile 2011.july $18^{\text {th }}$ 2012. Zhob. Prepared by planning and Development Department, Government of Balochistan, Quetta(in collaboration with) UNICEF United NationnChildren's fund provincial office in Balochistan, Quetta.pg 81.

Durand, J. D. (2015). The labor force in economic development: a comparison of international census data, 19461966. Princeton University Press.

Farooq, R. A. (1994). The education system in Pakistan: Issues and problems. Asia Society for PR.

Farooq, R. A. (1994). The education system in Pakistan: Issues and problems. Asia Society for PR.

Fatmi, Z., Hadden, W. C., Razzak, J. A., Qureshi, H. I., Hyder, A. A., \& Pappas, G. (2007). Incidence, patterns and severity of reported unintentional injuries in Pakistan for persons five years and older: results of the National Health Survey of Pakistan 1990-94. BMC public health, 7(1), 152.

Kemal, A. R., Irfan, M., \& Mahmood, N. (2003). The population of Pakistan: an analysis of 1998 population and housing census.

Kothari, C. R. (2004). Research Methodology: Methods and techniques. New Age International.

Kumar, S., \& Phrommathed, P. (2005). Research methodology(pp. 43-50). Springer US.

Mansoor, S. (1993). Punjabi, Urdu, English in Pakistan: A Sociolinguistic Study. Vanguard.

Mansoor, S. (2002). The role of English in higher education in Pakistan (Doctoral dissertation, University of Reading).

Mustafa, Z. (2005). Debate on medium of instruction. The Dawn Daily.

Rahman, T. (1991). A history of Pakistani literature in English. Vanguard.

Rahman, T. (2006). Language policy, multilingualism and language vitality in Pakistan. Trends in linguistics studies and monographs, 175,73 .

Rahman, T. (2007). The role of English in Pakistan with special reference to tolerance and militancy. Language policy, culture, and identity in Asian contexts, 219-239. 
Rehman, T. (2009). Language policy, language death and vitality in Pakistan. Emerging Issues in TEFL-Challenges for Asia, 3-30.

Rinartha, K., \& Suryasa, W. (2017, August). Comparative study for better result on query suggestion of article searching with MySQL pattern matching and Jaccard similarity. In Cyber and IT Service Management (CITSM), 2017 5th International Conference on (pp. 1-4). IEEE.

Sandholtz, J. H. (1997). Teaching with technology: Creating student-centered classrooms. Teachers College Press, Teachers College, Columbia University, 1234 Amsterdam Ave., New York, NY 10027.

Shaikh, B. T., Kahloon, A., Kazmi, M., Khalid, H., Nawaz, K., Khan, N., \& Khan, S. (2004). Students, stress and coping strategies: a case of Pakistani medical school. EDUCATION FOR HEALTH-ABINGDON-CARFAX PUBLISHING LIMITED-, 17, 346-353.

Shakil, A. F., \& Akhtar, S. H. Consideration of Islamic Values in the Educational Policies of Pakistan.

Shami, P. A., \& Hussain, K. S. (2006). Development of education in Pakistan. Academy of Educational Planning and Management, Ministry of Education.

Slavin, R. E., \& Davis, N. (2006). Educational psychology: Theory and practice.

Suryasa, I. W., Prayoga, I. G. P. A., \& Werdistira, I. W. A. (2017). An Analysis of Students' Motivation Toward English Learning As Second Language Among Students In Pritchard English Academy (PEACE). International Journal of Social Sciences and Humanities (IJSSH), 1(2), 43-50.

Wesley, E. B. (1937). Teaching the social studies: Theory and practice. DC Heath.

Winston, P. H., \& Simon, J. (1997). How to Speak. Derek Bok Center for Teaching and Learning, Harvard University. 